\title{
Quantitative morphometric and histopathological study in rabbit oviducts after microsurgical treatment
}

\author{
J. E. Luettges, A. Boeger, S. Nitschke-Dabelstein*, U. Pudlo*, G. Zwiens* \\ and H. Prinz† \\ Departments of Pathology, and *Gynecology and Obstetrics, and $\dagger$ Biological Statistics, \\ Philipps-University, 3550 Marburg, West Germany
}

\begin{abstract}
Summary. The histopathological lesions remaining after microsurgical tubal reanastomosis were investigated quantitatively by light microscopy and qualitatively by transmission and scanning electron microscopy. In 23 rabbit oviducts, the influence of the suture material poly-p-dioxanon and polyglactin-910 and post-operative time interval (6 and 12-15 weeks) was evaluated and compared with non-anastomosed contralateral oviducts as well as with those of unoperated controls. Except in the controls, partial deciliation, pathological kinocilia structure, microvilli and cytoplasmic blebs were found in all tissues, demonstrating an almost complete endosalpingeal restoration. A statistically significant increase of the muscular thickness was observed on the operated and unoperated sides and was due to fibrosis and expressed by cell/stroma ratio. Subepithelial microgland-like structures also appeared on both sides. As neither the kind of suture material nor time intervals led to differences in tissue reaction and, moreover, as similar alterations were found in the non-anastomosed oviducts, the lesions are presumed to be mainly the response to laparotomy.
\end{abstract}

\section{Introduction}

Microsurgical methods are well established for tubal reanastomosis and reconstruction as they guarantee the least iatrogenic damage to normal anatomical structures of the oviduct (Winston, $1975,1981 \mathrm{a}, \mathrm{b})$. Various surgical techniques and suture materials have been studied experimentally and their success is usually confirmed by healing and restoration of the endosalpinx at the anastomotic site (Stangel, Settles, Hereyniak, Freedman \& Stone, 1978; Bernhardt-Huth, Frantzen $\&$ Schlösser, 1981). The unoperated contralateral oviducts have rarely been considered as control (Patton \& Halbert, 1979; Eddy \& Bajpai, 1982). In the present light and electron microscopy study we have examined at various post-operative intervals the anastomosis and the adjacent segments, appropriate parts of the non-anastomosed contralateral oviducts and oviducts from animals that had never undergone laparotomy. We intended to investigate whether there were alterations independent from the surgical procedure and suture material and, if so, possibly to quantify them.

\section{Materials and Methods}

In 23 rabbits weighing $2000-2500 \mathrm{~g}$ unilateral tubal reanastomosis was performed. Another 10 animals served as controls. All rabbits were nulliparous, in oestrus and had never undergone any surgical procedure. Under general anaesthesia induced with $30 \mathrm{mg}$ pentobarbitone sodium $/ \mathrm{kg}$ i.v. and supplemented with halothane in nitrous oxide and oxygen, the right oviduct was exposed through a midline incision, exteriorized and supported on gauze sponges moistened with $0.9 \%(w / v)$ $\mathrm{NaCl}$ and kept wet with Ringer (DAB 7, Braun, Melsungen). Any bleeding was carefully stopped 
by electrocoagulation under a surgical microscope. The tube was cut in the isthmic region and a two-layer unsplinted re-anastomosis excluding the endosalpinx was performed under microsurgical conditions. The suture material, size 8.0 was monofile absorbable poly-p-dioxanon (PDS: Ethicon, Hamburg) in 12 animals (Group P) and polyfilament absorbable polyglactin 910 (Vicryl: Ethicon) in 11 animals (Group V).

At 6 (15 animals) or 12-15 (8 animals) weeks after operation when the rabbits were in oestrus the appropriate $2-\mathrm{cm}$ long segments on both sides were resected. For transmission electron microscopy (TEM) the anastomoses and corresponding contralateral segments from 18 rabbits ( 10 Group P, 8 Group V) were fixed in $2 \%$ glutaraldehyde in $0.1 \mathrm{M}$-cacodylate buffer. In 16 rabbits the adjacent $0.5-\mathrm{cm}$ long segments were prepared for light microscopy, embedded in paraffin wax, cut continuously into $5 \mu \mathrm{m}$ thin sections and alternately stained with haematoxylin and eosin and van Gieson's elastin stain. TEM specimens were post-fixed in $1 \% \mathrm{OsO}_{4}$ buffered with cacodylate, dehydrated in graded ethanols and embedded in Epon 812. Semithin sections were stained with methylene blue and azur II. Thin sections were stained with uranyl acetate and lead citrate and examined with a Siemens I Elmiskop. The anastomoses of 5 other animals were cut open longitudinally, pinned flat, fixed in $2 \%$ glutaraldehyde, dehydrated in graded ethanols and amylacetate, coated with gold under vacuum, critical-point dried with $\mathrm{CO}_{2}$ and examined by scanning electron microscopy (SEM: M7, ISI). The same procedures were followed for the unoperated controls. Morphometric light microscopy (Oberholzer, 1983) of 10 randomized sections from each tube was performed with a Leitz A.S.M. (Wetzlar) by grid-point counting using an hexagonal counting field (Universalcounting Ocular; Leitz, Wetzlar). The degree of fibrosis was evaluated by counting the number of muscle cells within 10 fields per cross-section. The thickness of the muscle layer was measured by an ocular micrometer (Leitz). The scale reading was taken from the smallest size in a right angle to a virtual tangent on the lamina propria. Statistical calculations ( $U$ test) were done with an electronic computer type $R \mathbf{4 4 0 .}$

\section{Results}

\section{Gross pathology}

Both oviducts showed a slightly palpable fibrosis in contrast to that of the smooth non-operated controls. Location of anastomoses was revealed by a slightly distended wall. Tubal patency was confirmed by free passage of fixative solution or microdissection. Mild adhesions were restricted to the serosa and mesosalpinx.

\section{Light microscopy}

A slight inflammatory cellular reaction was found in all oviducts, mainly in the subserous tissue and less in the muscular layer (Table 1). Neither the kind of suture material nor the interval after operation resulted in differences in the number of inflammation cells, which were lymphocytes and macrophages. The mucosa did not show any infiltration. The whole mucosal area seemed to have a slight but not significant increase with $16.4 \pm 2.5 \mathrm{~mm}^{2}$ in Group P (6 weeks) and $16.7 \pm 1.2 \mathrm{~mm}^{2}$ in the non-anastomosed side versus $14.6 \pm 1.9 \mathrm{~mm}^{2}$ in the non-operated control animals. There was a statistically significant $(P<0.05)$ thickening of the myosalpinx (Table 2$)$. This lesion was caused by fibrosis of the muscularis which was revealed by the cell/stroma ratio (Table 2). Immature subepithelial microgland-like structures were found in the anastomosed and in the contralateral oviducts, regardless of the kind of suture material (Pl. 1, Figs 1 \& 2). Glandular or tubular units were lined by flattened to cuboidal cells, which contained little mucus. Secretory granules were detected by TEM. Because of their resemblance to lesions known from the endocervix we have called these 
Table 1. Mean numbers (10 cross-sections/oviduct) of inflammatory cells in tissue adjacent to the anastomotic site and in contralateral oviducts of rabbits after anastomosis with PDS (Group P) or Vicryl

(Group V) 6 or 12 weeks earlier

\begin{tabular}{|c|c|c|c|c|c|c|c|c|c|}
\hline & \multicolumn{4}{|c|}{ Adjacent to anastomosis with PDS } & \multicolumn{4}{|c|}{ Adjacent to anastomosis with Vicryl } & \multirow{3}{*}{$\begin{array}{c}\text { Unoperated } \\
\text { control } \\
(\mathrm{N}=6)\end{array}$} \\
\hline & \multicolumn{2}{|c|}{$\begin{array}{l}\text { Anastomosed } \\
\text { side }\end{array}$} & \multicolumn{2}{|c|}{$\begin{array}{l}\text { Contralateral } \\
\text { side }\end{array}$} & \multicolumn{2}{|c|}{$\begin{array}{l}\text { Anastomosed } \\
\text { side }\end{array}$} & \multicolumn{2}{|c|}{$\begin{array}{l}\text { Contralateral } \\
\text { side }\end{array}$} & \\
\hline & $\begin{array}{l}6 \text { weeks } \\
(\mathrm{N}=4)\end{array}$ & $\begin{array}{l}12 \text { weeks } \\
(\mathrm{N}=4)\end{array}$ & $\begin{array}{l}6 \text { weeks } \\
(N=4)\end{array}$ & $\begin{array}{l}12 \text { weeks } \\
(\mathrm{N}=4)\end{array}$ & $\begin{array}{l}6 \text { weeks } \\
(N=4)\end{array}$ & $\begin{array}{c}12 \text { weeks } \\
(\mathrm{N}=4)\end{array}$ & $\begin{array}{l}6 \text { weeks } \\
(N=4)\end{array}$ & $\begin{array}{l}12 \text { weeks } \\
(N=4)\end{array}$ & \\
\hline \multicolumn{10}{|l|}{ Tunica serosa } \\
\hline Lymphocytes & 5 & 7 & 1 & 1 & 11 & 10 & 1 & 1 & - \\
\hline Macrophages & 3 & 4 & - & - & 3 & 3 & - & - & - \\
\hline Granulocytes & - & - & - & - & - & - & - & - & - \\
\hline \multicolumn{10}{|l|}{ Tunica muscularis } \\
\hline Lymphocytes & 3 & 1 & 1 & 1 & 2 & 3 & 1 & 1 & - \\
\hline Macrophages & - & $\ldots$ & - & - & - & - & - & - & - \\
\hline Granulocytes & - & - & - & - & - & - & - & - & - \\
\hline \multicolumn{10}{|l|}{ Tunica mucosa } \\
\hline Lymphocytes & - & - & - & - & - & - & - & - & - \\
\hline Macrophages & - & - & - & - & - & - & - & - & - \\
\hline Granulocytes & - & - & - & - & - & - & - & - & - \\
\hline
\end{tabular}

Table 2. Thickness of the muscular layer $(\mu \mathrm{m})$ and degree of fibrosis expressed by the average of cell/stroma ratio per 10 counting fields

\begin{tabular}{|c|c|c|c|c|}
\hline & $\begin{array}{l}\text { Mean } \pm \text { s.d. } \\
\text { diam. of } \\
\text { muscularis } \\
(\mu \mathrm{m})\end{array}$ & Significance & $\begin{array}{c}\text { Cell : stroma } \\
\text { ratio } \\
(\% \text { cells })\end{array}$ & Significance \\
\hline \multicolumn{5}{|l|}{ Adjacent to PDS } \\
\hline 6 weeks $(N=4)$ & $220 \pm 38$ & N.S. to PDS or Vicryl & 57 & N.S. To Vicryl \\
\hline 12 weeks $(\mathrm{N}=4)$ & $247 \pm 39$ & N.S. to PDS or Vicryl & 53 & N.S. to Vicryl \\
\hline Contralateral side & & & & \\
\hline $\begin{array}{r}6 \text { weeks }(N=4) \\
12 \text { weeks }(N=4)\end{array}$ & $\begin{array}{l}185 \pm 11 \\
180 \pm 9\end{array}$ & $\begin{array}{l}\text { N.S. to anastomosed side } \\
\text { N.S. to anastomosed side }\end{array}$ & $\begin{array}{l}61 \\
61\end{array}$ & $\begin{array}{l}P<0.05 \text { to anastomosed side } \\
P<0.05 \text { to anastomosed side }\end{array}$ \\
\hline \multicolumn{5}{|l|}{ Adjacent to Vicryl } \\
\hline $\begin{array}{r}\text { Anastomosed side } \\
6 \text { weeks }(N=4) \\
12 \text { weeks }(N=4)\end{array}$ & $\begin{array}{l}202 \pm 26 \\
189 \pm 16\end{array}$ & $\begin{array}{l}\text { N.S. to PDS or Vicryl } \\
\text { N.S. to PDS or Vicryl }\end{array}$ & $\begin{array}{l}54 \\
59\end{array}$ & $\begin{array}{l}\text { N.S. to PDS } \\
\text { N.S. to PDS }\end{array}$ \\
\hline Contralateral side & & & & \\
\hline $\begin{array}{r}6 \text { weeks }(N=4) \\
12 \text { weeks }(N=4)\end{array}$ & $\begin{array}{l}184 \pm 11 \\
180 \pm 9\end{array}$ & $\begin{array}{l}\text { N.S. to anastomosed side } \\
\text { N.S. to anastomosed side }\end{array}$ & $\begin{array}{l}61 \\
61\end{array}$ & $\begin{array}{l}P<0.05 \text { to anastomosed side } \\
P<0.05 \text { to anastomosed side }\end{array}$ \\
\hline $\begin{array}{l}\text { Unoperated control } \\
\qquad(N=6)\end{array}$ & $127 \pm 9$ & $\begin{array}{l}P<0.01 \text { to anastomosed side, } \\
\text { PDS and Vicryl }\end{array}$ & 74 & $\begin{array}{l}P<0.01 \text { to anastomosed side, } \\
\text { PDS and Vicryl }\end{array}$ \\
\hline
\end{tabular}

structures 'microglands'. They were located at the base of the longitudinal folds, but were not continuous with the lumen. Their number increased by 12 weeks after operation (Table 3 ). They were never observed in control animals. In contralateral non-anastomosed tubes their distribution was more diffuse than local (Table 3). Pseudodiverticula consisting of ectopic endothelium in the myosalpinx could be found only at the anastomosal cut. 
Table 3. The average incidence, number and distribution (relative frequency) of microglands in the subepithelial stroma after oviducal anastomosis per 10 cross-sections

\begin{tabular}{|c|c|c|c|c|c|}
\hline & \multirow{2}{*}{$\begin{array}{l}\% \text { of cross-sections } \\
\text { with microglands }\end{array}$} & \multicolumn{2}{|c|}{$\begin{array}{c}\text { Number } \\
(\% \text { frequency) }\end{array}$} & \multicolumn{2}{|c|}{$\begin{array}{c}\text { Distribution } \\
(\% \text { frequency) }\end{array}$} \\
\hline & & $<5$ & $5-10$ & Diffuse & Local \\
\hline \multicolumn{6}{|l|}{ Adjacent to PDS } \\
\hline \multicolumn{6}{|l|}{ Anastomosed side } \\
\hline 6 weeks $(N=4)$ & 32 & 52 & 38 & 18 & 32 \\
\hline 12 weeks $(\mathrm{N}=4)$ & 56 & 47 & 43 & 58 & 0 \\
\hline \multicolumn{6}{|l|}{ Contralateral side } \\
\hline 6 weeks $(N=4)$ & 35 & 21 & 8 & 37 & 3 \\
\hline 12 weeks $(N=4)$ & 41 & 30 & 5 & 31 & 17 \\
\hline \multicolumn{6}{|l|}{ Adjacent to Vicryl } \\
\hline \multicolumn{6}{|l|}{ Anastomosed side } \\
\hline 6 weeks $(N=4)$ & 31 & 52 & 41 & 37 & 23 \\
\hline 12 weeks $(N=4)$ & 58 & 27 & 68 & 60 & 32 \\
\hline \multicolumn{6}{|l|}{ Contralateral side } \\
\hline 6 weeks $(N=4)$ & 31 & 21 & 8 & 37 & 3 \\
\hline 12 weeks $(\mathrm{N}=4)$ & 41 & 30 & 5 & 31 & 17 \\
\hline \multicolumn{6}{|l|}{ Unoperated control } \\
\hline$(N=6)$ & - & - & - & - & - \\
\hline
\end{tabular}

\section{Scanning electron microscopy}

At the anastomotic site mucosal folds were interrupted and slightly broadened by 6 weeks after operation. Adjacent folds and contralateral controls showed a regular pattern, as in unoperated animals, with a normal distribution of ciliated and secretory cells. However, in single ciliated cells, a partial deciliation and shortening of cilia were found on both sides (Pl. 1, Fig. 3). Furthermore, large vesicles and microvilli appeared on the surface of secretory and ciliated cells (PI. 2, Figs 5 \& 6). Single misshaped, peg cells were also observed. These lesions were never seen in unoperated controls.

\section{Transmission electron microscopy}

At 6 weeks, mucosal folds of all oviducts were covered by columnar secretory and ciliated cells. Apical cell borders of ciliated cells demonstrated cytoplasmic blebs containing hyaloplasm, few ribosomes and fragments of microtubuli. Amongst normal ciliated cells partly deciliated cells were observed with slender or distended kinocilia presenting an abnormal $9+2$ arrangement of the microtubuli (Pl. 1, Fig. 4). Several ciliated cells had a few kinocilia interspersed with long finger-like microvilli at the apex (Pl. 2, Fig. 5). Macrophages, including suture fragments of PDS and Vicryl, were found within the subepithelial stromal tissue, myosalpinx and perisalpinx. Fibrosis of the oviducts was established by the presence of bundles of mature collagen fibres with intermixed elastic lamellae and several fibrocytes lacking signs of fibrillogenesis.

At 12-15 weeks, the alterations observed at the epithelial surface were similar in the anastomosed and unoperated contralateral oviducts and included cytoplasmic blebs (Pl. 2, Fig. 7), focal deciliation, stumps of kinocilia and abnormal arrangements of microtubuli. In addition narrow microglandular epithelial formations of varied maturity appeared (P1. 1, Figs 1 \& 2) at the base of the mucosal folds. Some immature cells were characterized by lack of kinocilia, secretory granules and an increase of free ribosomes. Increasing maturity was demonstrated by the appearance of microvilli, kinocilia, secretory granules, rough endoplasmic reticulum and numerous mitochondria. 

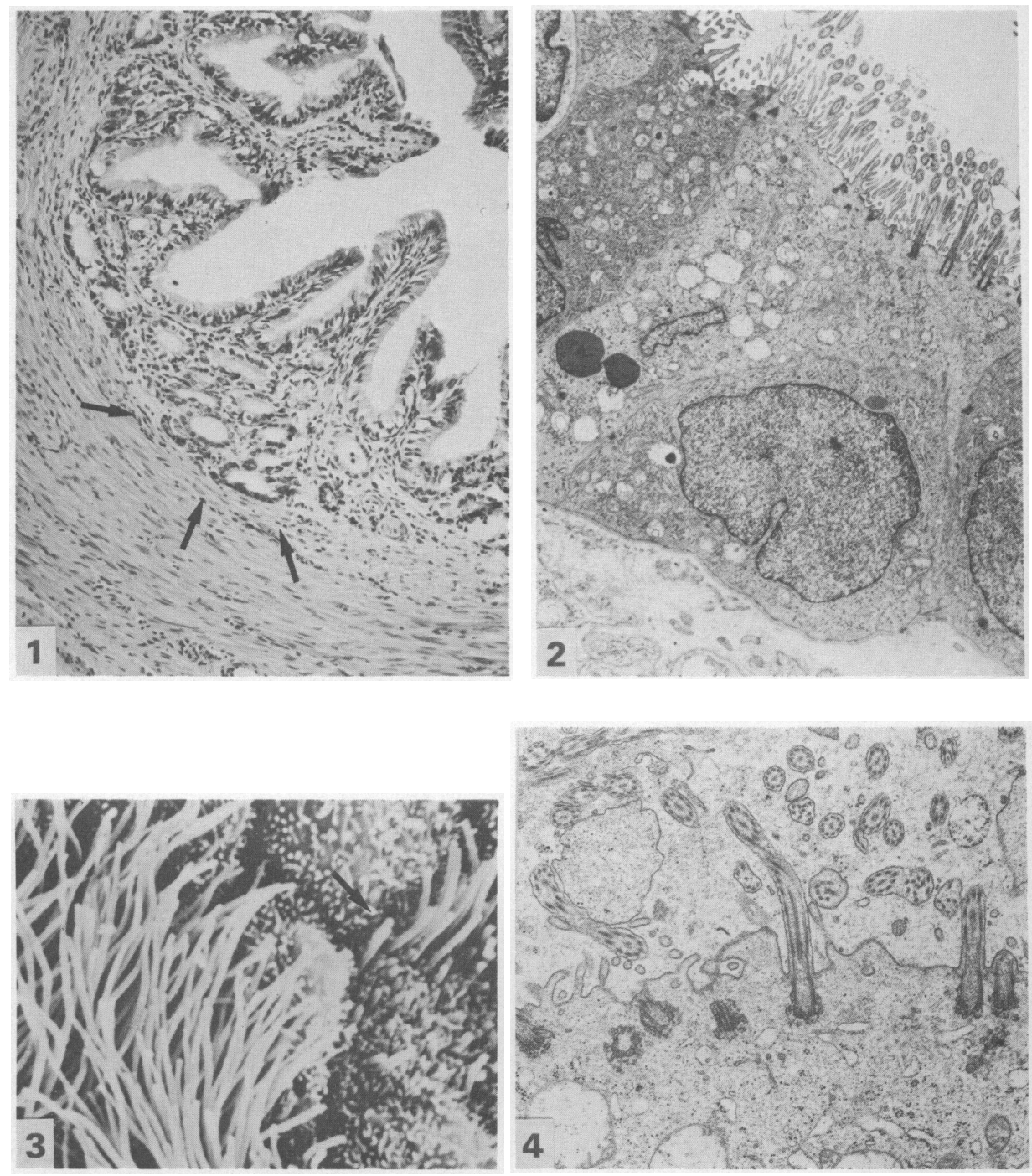

Fig. 1. Light microscopy, cross-section of contralateral non-anastomosed oviduct with a group of subepithelial microglands (arrows). $\mathrm{H} \& \mathrm{E}, \times 30$.

Fig. 2. Transmission electron microscopy showing microglands with focal ciliation and microvilli at the epithelial surface (anastomosed oviduct, Group V). $\times 5175$.

Fig. 3. Scanning electron microscopy, partial deciliation, stumps of cilia (arrow) at the right (non-anastomosed oviduct). $\times 3750$.

Fig. 4. TEM, reduced number of cilia and abnormal $9+2$ arrangement of microtubuli (anastomosed oviduct, Group P). $\times 9750$. 

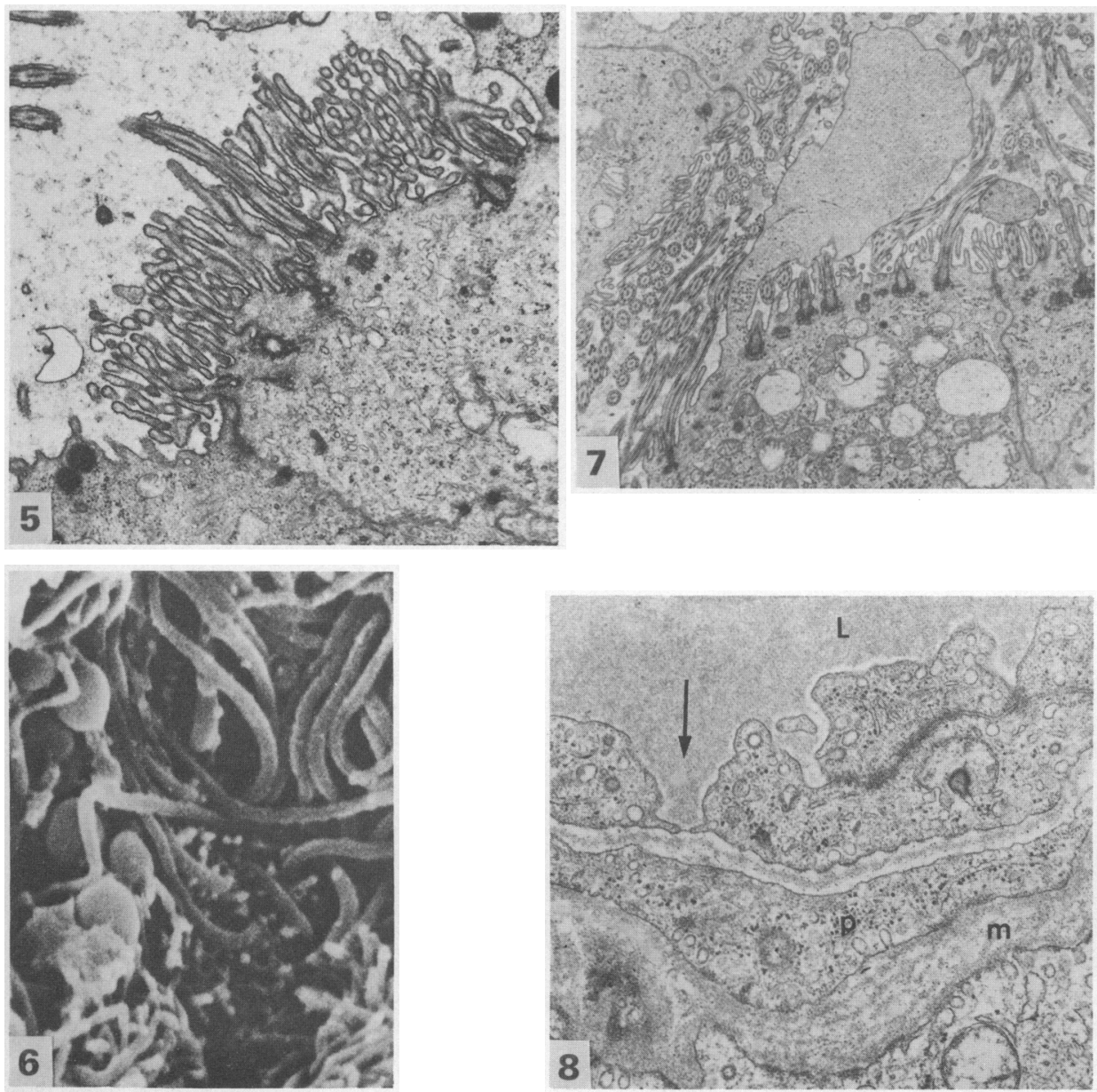

Fig. 5. TEM, increase of dense and long microbilli at the surface of a secretory cell (nonanastomosed oviduct). $\times 10500$.

Fig. 6. Several blebs among normal cilia (non-anastomosed oviduct). $\times 11250$.

Fig. 7. Cytoplasmic bleb protruding at the surface of a ciliated cell (non-anastomosed oviduct). $\times 5400$.

Fig. 8. Postcapillary venule with fenestra (arrow), unilamellar basement membrane, pericyte (p) and multilamellar membrane (m) and lumen (L) (anastomosed oviduct, Group V). $\times 17250$. 
In the thickened tubal wall there were numerous blood capillaries and postcapillary venules in the subepithelial stroma layer and myosalpinx. The endothelium contained many uncoated and coated micropinocytotic vesicles with hyaloplasm, ribosomes, and microtubuli (Pl. 2, Fig. 8). A continuous unilamellar or multilamellar basement membrane was present beneath the vascular endothelial layer. Regardless of the tubal diameter, lymphatic vessels were observed only in the perisalpinx. They were characterized by numerous endothelial vesicles, a few intercellular attachment sites, a discontinuous basement membrane and lack of pericytes.

\section{Discussion}

Corresponding to the experiments of MacKay \& Khoo (1972), Patton \& Halbert (1979), Eddy \& Bajpai (1982), our results document an almost complete restoration and healing of the oviduct by 6 and 12-15 weeks after operation. The above-mentioned authors report qualitative morphological alterations. Our morphometric investigations have attempted to quantify the lesions so that comparisons of tubal damage can be made. The main results were a persistent measurable and even increasing thickening of the tubal wall due to fibrosis and the appearance of subepithelial microglands. There were no significant differences in tissue reaction with the two suture materials used, and, as concluded by Riddick, DeGracia \& Maenza (1977) new materials such as PDS are not superior to Vicryl for tubal surgery. The difference in suture materials seems to be of minor importance as similiar lesions were found on the non-anastomosed side, and other factors may influence tissue reaction.

In addition to our morphometrically quantified results, we found lesions in the epithelial layer that could be qualitatively characterized by TEM and SEM. The endosalpinx showed the well known slight disruption at the anastomotic site (McComb, Halbert \& Gomel, 1980; BernhardtHuth et al., 1981; Eddy \& Bajpai, 1982). Secretory and ciliated cells were normally distributed. However, single cells of both types were irregularly shaped. Placed among cilia and microvilli large irregular cytoplasmic blebs could be demonstrated on both sides-in the anastomotic site, with its adjacent epithelial layer, and surprisingly in contralateral segments. Similar alterations with formation of blebs were found in different tissues and under various conditions by Frenzel, Hücker \& Kremer (1977) and Frenzel, Kremer \& Hücker (1977) in hepatocytes and liver sinusoids after hypoxaemic and toxic damage and after irradiation, by Schaffner \& Popper (1961) in proliferating bile ductules and by Hammersen \& Wendler (1972) in immature mesenchymal and endothelial cells from allantois and yolk-sac vessels. This phenomenon of cytoplasmic blebs seems to be a pathological cellular answer to cell injury as well as a physiological process in differentiating and growing cells. Both might be an explanation for our findings. By light and electron microscopy, microglands could be identified and quantified, ipsi- and contralateral, but never in the control oviducts. Their epithelial nature and secretory activity was proved by TEM. These glands have not been reported before. They are certainly of different origin from the pseudodiverticula due to traumatically spread mucosa seen in the anastomosis (Winston, 1975; Riddick, et al., 1977; Bernardt-Huth et al., 1981). The invasive ability of the tubal epithelium per se is discussed by Benjamin \& Beaver (1951) as the origin for salpingitis isthmica nodosa, which may have, in its very early stages, a certain resemblance to our findings. The microglands might be better comparable to the dark cells reported by MacKay \& Khoo (1972) and might be a kind of chronic epithelial hyperregeneration caused by chronic tubal damage. They may be extensions of the longitudinal folds, with a loss of connection to the lumen. Such a process could be maintained by fibrosis of the muscular layer with its statistically significant increase of thickness. Furthermore, partial deciliation, abnormal kinocilia structure and increase of long microvilli were found in all the tissues examined except those of the controls.

As nearly all the reported alterations were practically independent from the sutures, we believe that laparotomy per se is of more importance and might initiate a chronic self-maintaining damage which is not mediated by a cellular reaction or inflammation. Our results might be explained by 
disruption of the microcirculation during operation with an insufficient uptake of plasma and fluid by endo- and myosalpingeal venules. In this context, function, frequency and distribution of lymphatic vessels have to be discussed. We always found lymphatic vessels in the perisalpinx. Böger \& Rössner (1980) found a lack of lymphatic vessels except in periureteral tissue and as a postoperative complication in healing with fibrosis. Alterations of the non-anastomosed contralateral oviducts in comparison to the unoperated oviducts may support our thesis that the suture material is not solely responsible for the tissue reaction.

Whether or not this amount of tubal fibrosis is of pathological practical importance for tubal motility and fertility has still to be analysed or whether there is any connection or possible explanation for infertility in young women after pelvic surgery beside the well-known problem of adhesions.

The experiments were kindly supported by the Kuhlemann-Stiftung e.V.

\section{References}

Benjamin, C.L. \& Beaver, D.C. (1951) Pathogenesis of salpingitis isthmica nodosa. Am. J. clin. Path. 21, 212-222.

Bernhardt-Huth, D., Frantzen, Ch. \& Schlösser, H.W. (1981) Morphology of rabbit oviduct after microsurgical techniques for reanastomosis of the isthmus or ampulla. Arch. Gynäk. 230, 251-262.

Böger, A. \& Rössner, N. (1980) Elektronenmikroskopische Untersuchungen des LymphgefäBsystems des Ureters. Urologe 19, 145-152.

Eddy, C.A. \& Bajpai, V.K. (1982) Healing and restoration of fertility following microsurgical transection and anastomosis of the rabbit oviduct. Fert. Steril. 38, 354-363.

Frenzel, H., Hücker, H. \& Kremer, B. (1977) Die Lebersinusoide der Ratte nach fraktionierter Telekobalt-Bestrahlung. Virch. Arch. A Path. Anat. Histol. 375, 35-51.

Frenzel, H., Kremer, B. \& Hücker, H. (1977) The liver sinusoids under various pathological conditions. A TEM and SEM study of rat liver after respiratory hypoxia, telekobalt-irradiation and endotoxin application. In Kuppfer Cells and Other Liver Sinusoidal Cells, pp. 213-222. Eds E. Wisse \& K. L. Knook. Elsevier/North-Holland Biomedical Press, Amsterdam.

Hammersen, F. \& Wendler, W. (1972) Multivesikuläre Strukturen in verschiedenen Wandzellen- und Dottersackgefäßen des Hühnchens. Z. Zellforsch. mikrosk. Anat. 130, 243-248

MacKay, E.V.\& Khoo, S.K. (1972) Reaction in the rabbit fallopian tube after plastic reconstruction. II. Histopathology. Fert. Steril. 23, 207-216.
McComb, P. T., Halbert, S. A. \& Gomel, V. (1980) Pregnancy, ciliary transport, and reversed ampullary segment of the rabbit fallopian tube. Fert. Steril. 34, 386-390.

Oberholzer, M. (1983) Morphometrie in der Klinischen Pathologie. Springer Verlag, Berlin.

Patton, J.L. \& Halbert, S.A. (1979) Electron microscopic examination of the rabbit oviductal ampulla following microsurgical end-to-end anastomosis. Fert. Steril. 32, 691-696.

Riddick, D.H., DeGracia, C.T. \& Maenza, R.M. (1977) Comparison of polyglycolic acid sutures in reproductive tissue. Fert. Steril. 28, 1220-1225.

Schafiner, F. \& Popper, H. (1961) Electron microscopic studies of normal and proliferated bile ductules. $\mathbf{A m}$. J. Path. 38, 393-410.

Stangel, J.J., Settles, H. E., Hereyniak, J.F., Freedman, W.L. \& Stone, M.L. (1978) Microsurgical anastomosis of the rabbit oviduct using 9-0 monofilament polyglygolic acid suture. Fert. Steril. 30, 210-215.

Winston, R.M.L. (1975) Microsurgical reanastomosis of the rabbit fallopian tube and its functional and pathological sequela. Br. J. Obstet. Gynaec. 82, 513522.

Winston, R.M.L. (1981a) Progress in tubal surgery. Clinic Obstetrics and Gynecology 8, 653-679.

Winston, R.M.L. (1981b) Is microsurgery necesssary for salpingostomy? The evaluation of results. Aust. N. Z. Jl Obstet. Gynaec. 21, 145-154. 